\title{
SPADA Implementation on English E-Learning Course: Mechanical Engineering Students' Perspectives
}

Tutut Nani Prihatmi ${ }^{1}$, Maria Istiqoma ${ }^{2}$

${ }^{1}$ Department of Mechanical Engineering, National Institute of Technology Malang, Indonesia

2Department of Architecture, National Institute of Technology Malang, Indonesia Email: tutut.nani@lecturer.itn.ac.id

\begin{tabular}{ll}
\hline Article History & Received : January $9^{\text {th }} 2021$ \\
& Revision : February $13^{\text {th }} 2021$ \\
& Publication : March 30th 2021
\end{tabular}

\begin{abstract}
This study investigates the Mechanical Engineering students' perspectives on their E-learning experience using SPADA as the primary platform in learning English, including understanding its features and material delivered, difficulties during the learning process, and suggestions to improve the quality of learning English through SPADA ITN Malang. As the Indonesian government requires every school and institution to begin implementing E-learning, starting from March 2020, in the National Institute of Technology (ITN) Malang, all learning activities that have been performed conventionally converted into virtual learning using the web-based learning management system named SPADA ITN Malang. The findings show that SPADA ITN Malang has positive appraisal by the students in accessibility, comprehension, and satisfaction aspect. However, the difficulties found, which were internet connection and the lack of discussions, should be addressed with suitable learning strategies to create a better English learning environment for the nonEnglish department students.
\end{abstract}

Keywords: Student Perspective, SPADA, English E-Learning.

\section{INTRODUCTION}

The issues emerging from the COVID-19 pandemic outbreak become a significant challenge in education. With the consideration of preventing the spread of a more massive virus to students, Study from Home or online learning is then implemented at all education levels in Indonesia, starting from elementary, junior high, high school to tertiary levels. Likewise, in the National Institute of Technology Malang, all learning activities that have been performed conventionally must be converted into virtual learning or online learning. 
There are different terms used for online learning, including e-learning, internet learning, networked learning, web-based learning, and distance learning, all imply that the learner is at a distance from the teacher and uses some technology access learning materials. Technology is the tool for communication between students and teachers (Ally, 2004). Wahono (2008) states that e-learning is a type of teaching and learning that allows the materials delivered to students using the internet, intranet, or other computer network media. Meanwhile, the materials are also in all kinds of formats, such as videos, slideshows, or office documents. Initially, E-learning already has enormous potential to face the newest challenges of the world of education. E-learning is not the most recent issue in education, but it has become the most discussed topic by academic articles during this COVID-19 pandemic outbreak as the world started to implement this in all levels of education. E-learning becomes the center of attention in education, to continue to be studied, applied, and improved from various aspects by educational experts and practitioners for use in formal and non-formal education.

Higher Education can be considered more prepared to face online learning in terms of preparation because some of them already have their own online Learning Management System (LMS). LMS is a global term for course management based on the computer system. One of them is the Open and Integrated Indonesia Online Learning (PDITT) program, which has been launched by the Indonesian government in October 2014. In 2016, the PDITT system program changed its name to Online Learning System (SPADA). One of the SPADA Indonesia program's initial goals was to increase equitable access to quality learning in universities throughout Indonesia by providing opportunities for students from one particular university to take specific courses from other universities (Directorate of Learning, 2019). With the COVID-19 pandemic requires online lectures, SPADA Indonesia has become one of the primary learning tools used in many institutions, including the National Institute of Technology Malang.

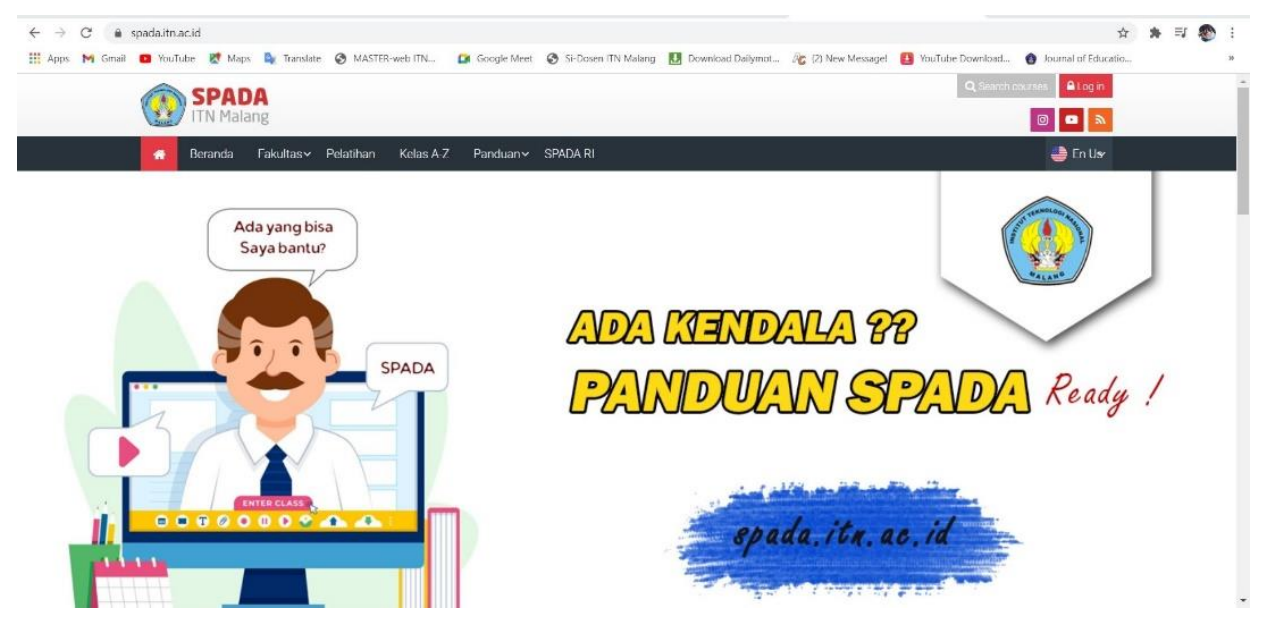


Fig. 1. SPADA ITN Malang Welcome Page (2020)

Previous researches by Sujarwo et al. (2020), Wijayanengtias (2020), and Saputro (2020) concluded that both students and teachers have positive perspectives on online learning during the COVID-19 pandemic. Since SPADA is one of the web-based e-learning platforms managed by universities, several studies have been specially conducted to determine its effectiveness in helping the e-learning process. The online LMS platforms are proven viable for learning even though it has various convenience degrees as concluded in Sudiana (2016), Saputro (2019), and Ulfa and Puspaningtyas (2020).

However, this research investigates explicitly Mechanical Engineering students' perspectives on their English course E-learning while entirely using SPADA in 14 meetings without any direct face-to-face learning. In Mechanical Engineering Department, English is a compulsory course in the first semester with two credits. As a non-expertise subject, English lecturers need to put more effort into organizing a comfortable and enjoyable online learning process. One of the efforts made is to compile and write up to date, authentic, contextual, and not tiresome study materials in SPADA. In an entirely online course circumstance where all teaching and administrative support is provided online (Neilson, 2006), students' perspective holds an essential role in learning quality improvement. It is necessary to examine whether students have adapted to and satisfied with the e-learning process (Coman et. al., 2020). Their remarks will show the impact of their new learning circumstance and how further improvement is needed to reduce the effect.

In line with the effort to improve the quality of learning using SPADA ITN Malang, this study aims to investigate how Mechanical Engineering students view the use of SPADA as the leading platform in learning English, the level of understanding of its features and material delivered, difficulties encountered during the learning process, and additional suggestions. Therefore, the results can be used as a source of support for the development of English course in SPADA ITN Malang and can be a rationale for designing or using SPADA for other universities.

\section{METHOD}

This research was conducted using a qualitative descriptive method. Creswell (in Raco, 2010) defines the qualitative method as an approach to search or explore and understand a central phenomenon, while the data are taken through interviews, field observations, or existing documents. The researcher is the critical instrument in collecting data. In this research, the data collection techniques were questionnaires and interviews. The subjects 110 were fifty-eight (58) undergraduate students of Mechanical Engineering taking the English courses in the even semester of the 2019/2020 academic year. The questionnaire consisted of 18 items that covers the demographic, learning preferences, difficulties, and their 
expectations of learning generally and of learning online using SPADA ITN Malang. Interviews then conducted to confirm observations. The results of the questionnaires and interviews were described in descriptive data.

Data analysis components include data collection, data display, data reduction, conclusion withdrawal, and verification (Gunawan, 2013). Verification was done by rechecking the data reduction and data display so that the conclusions drawn do not deviate. The data analysis procedure is shown in Fig.2.

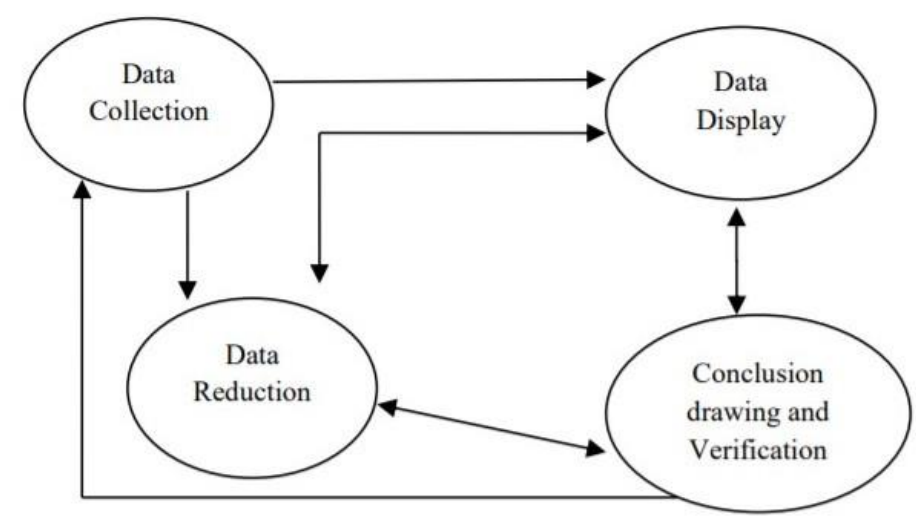

Fig. 2. Mile and Huberman's (1994) model of data analysis in Supardi (2016)

\section{RESULTS AND DISCUSSION}

Of the 110 questionnaires distributed, the responses obtained were 58. Mechanical Engineering students are the majority of men. 7.8\% of respondents (3 students) are female, while the rest, 92.2\% (48 students), are male. The questionnaires results are compiled then reduced into three assessment aspects as shown in Table 1.

Table 1 - Student's questionnaires result on SPADA implementation

\begin{tabular}{lll} 
Assessment Aspect & $\begin{array}{l}\text { Positive } \\
\text { Feedback }\end{array}$ & $\begin{array}{l}\text { Negative } \\
\text { Feedback }\end{array}$ \\
\hline Accessibility & $57 \%$ & $43 \%$ \\
\hline Course Comprehension & $86 \%$ & $14 \%$ \\
\hline Satisfaction level & $86 \%$ & $14 \%$ \\
\hline
\end{tabular}

Accessibility means the ease level in accessing and operating SPADA ITN Malang. All ITN Malang courses are required to use SPADA ITN Malang, which will have the possibility of causing an overload in the server's bandwidth. However, the problems that arise were not the difficulty of accessing the course but finding the course needed. $43 \%$ of respondents (25 students) found that they need more time 
in exploring the page to find the course and that the interface is less user friendly, while $57 \%$ of respondents (33 students) claimed that they had no significant problems.

Course comprehension refers to the students' comprehension of the English materials delivered in SPADA ITN Malang. There are nine topics available, complete with the theories, external learning URLs, videos, assignments, and grades for each assignment. $86 \%$ of respondents (50 students) stated that the course material is easy to understand, while the rest (14\%) stated the opposite, that they had some difficulties in understanding the materials.

Satisfaction level refers to how students generally assess the whole learning process through SPADA ITN Malang. This includes the complete availability of features and benefits they got. SPADA ITN Malang has been equipped with various features that can help students during online learning. As a result, $86 \%$ of respondents (50 students) said they were quite satisfied with the features offered, while only $14 \%$ or eight students said they were not satisfied. This dissatisfaction rate is closely related to the fact that $14 \%$ of students found some difficulties finding SPADA ITN Malang course.

Meanwhile, data collected from interviews were generated into three assessment aspects, namely advantage, disadvantage, and suggestion, as displayed in Table 2.

Table 2 - Student's interview results on SPADA implementation

\begin{tabular}{lll}
\hline Assessment Aspect & Statement & Percentage \\
\hline Advantage & Practical & $43 \%$ \\
\hline & Easy to access & $14 \%$ \\
\hline Disadvantage & Systematic & $43 \%$ \\
\hline & Low internet connection & $44 \%$ \\
\hline Suggestion & Lack of understanding of the material & $28 \%$ \\
\hline & No significant problem & $28 \%$ \\
\hline & More features & $25 \%$ \\
\hline & Live interaction & $25 \%$ \\
\hline & No suggestion & $50 \%$ \\
\hline
\end{tabular}


As can be seen in Table 2, SPADA ITN Malang is assessed as a practical and systematic application. Relevant result found by Saputro (2019) while assessing Madrasa teachers concluded that SPADA's application could show positive attributes that are practical and easy to use. Online learning is beneficial, even though it is not entirely efficient considering the obstacles they encounter.

Regarding the disadvantages, Table 2 shows that internet quality was the major problem reported by $44 \%$ of respondents during using SPADA ITN Malang. For ITN Malang Mechanical Engineering students, this online learning is the first time experienced, so they need many adjustments in technology adaptation, finance, and learning strategies (Haiyudi, 2021). As the offline lectures were closed and the activities in Malang city were limited, most students returned to their hometown. Their various locations caused variations in internet connection-level obtained during the learning process, although SPADA ITN Malang is web-based. The more complex a web page is, the slower it will load. Other than that, E-learning system employs some sort of technology in the process, so it was never expected to be an expense saving system. To help with the internet cost, the students got internet assistance from the Ministry of Education and Culture and ITN Malang in the form of cash to buy data packages. Apart from these two obstacles, $28 \%$ of respondents stated that there is no significant problem in using SPADA ITN Malang and considered this web-based application is sufficient to meet their needs of learning.

Suggestions given by the respondents are not varied. $50 \%$ of respondents stated that they have no additional suggestions for improving SPADA ITN Malang as they assumed the features were already sufficient, helpful, and easy to operate. While $50 \%$ of respondents suggested improving the quality by adding more helpful features such as direct notification, direct forum, video live, video tutorials, and a more straightforward design. Out of the 50\% suggestions added, half of them suggested the teachers use video tutorials for the materials and use direct interaction. In line with the use of video, Haiyudi (2021) states that teachers are expected to produce video learning by themselves for the learning materials, as it will increase the emotional bond between students and teachers. 


\section{CONCLUSION}

Education is not only about how to access (Anderson, 2004). The education system's sudden changes require students to feel new situations and adjust themselves (Taynton, 2020). This adjustment involves panic, stress, and anxiety, which will form the students' initial perceptions. As a web-based learning management system developed by ITN Malang Instructional Development Institutions, SPADA ITN Malang has proven to have a positive appraisal and high satisfaction level according to the students' perceptions. The advantages are accessibility, practicality, and a more systematic teaching-learning and assessment procedure. While the disadvantages are the difficulties with an internet connection and the lack of understanding. It is the lecturer's and institution's responsibility to resolve the disadvantages found and provide a better learning environment that will further improve the quality and effectiveness of English language learning acquisition, especially for non-English department students.

\section{REFERENCES}

Anderson, Terry. (2004). Toward A Theory of Online Learning. In Theory and Practice of Online Learning. Canada: Athabasca University.

Ally, Mohammed. (2004). Foundations of Educational Theory for Online Learning. In Theory and Practice of Online Learning. Canada: Athabasca University.

Coman, Claudiu; Țîru, Laurențiu G.; Meseșan-Schmitz, Luiza; Stanciu, Carmen; Bularca, Maria C. (2020). Online Teaching and Learning in Higher Education during the Coronavirus Pandemic: Students' Perspective. Sustainability 12, no. 24: 10367. https://doi.org/10.3390/su122410367 taken January $28^{\text {th }}$, 2021.

Coldwell-Neilson, Jo \& Craig, Annemieke \& Goold, A. (2006). Student Perspectives of $\begin{array}{llll}\text { Online } & \text { learning. } & 97 & -\end{array}$ https://www.researchgate.net/publication/233725899 Student Perspecti ves of Online learning taken January $10^{\text {th }}, 2021$.

Direktorat Pembelajaran. (2019). Panduan Proses Pembelajaran Daring SPADA 2019. Jakarta: Kemeristekdikti

Gunawan, Imam. (2013). Metode Penelitian Kualitatif. Jakarta: Bumi Aksara

Haiyudi, \& Art-In, S. (2021). Challenges, Strategies, and Solutions of Teaching Bahasa Indonesia in Covid-19 Crises:Case in Khon Kaen University. Indonesian Journal on Learning and Advanced Education (IJOLAE), Vol. 3 (2),142-152, 
http://journals.ums.ac.id/index.php/ijolae/article/view/12369 taken January 22nd, 2021.

Raco, J. R. (2010). Metode Penelitian Kualitatif: Jenis, Karakteristik, dan Keunggulannya. Jakarta: Grasindo

Saputro, B., \& Tri Susilowati, A. (2019). Effectiveness of Learning Management System (LMS) on In-Network Learning System (SPADA) Based on Scientific. Journal for the Education of Gifted Young Scientists, 7(3), 481-498. DOI: http://dx.doi.org/10.17478/jegys.606029 taken Januari 3rd, 2020.

Sudiana, R. (2016). Efektifitas Penggunaan Learning Management System Berbasis On Line. JPPM, 201-209. https://jurnal.untirta.ac.id/index.php/IPPM/article/view/998 taken January $12^{\text {th }}, 2021$.

Supardi. (2016). Language Power in Courtroom: The Use of Persuasive Feature Statement. Indonesian Journal of Applied Linguistics, Vol. 6 No(1), pp. 70-78. https://www.researchgate.net/publication/305740381 Language power in courtroom The use of persuasive features in opening statement taken January 22nd, 2021.

Taynton, Yvonne. (2000). Online Learning: A Student's Perspective. https://www.ascilite.org/conferences/coffs00/papers/yvonne taynton.pd f taken January 24th, 2021.

Ulfa, M. \& Puspaningtyas, N.D. (2020). The Effectiveness of Blended Learning Using A Learning System In Network (Spada) In Understanding of Mathematical Concept. Matematika dan Pembelajaran Volume 8 (1). https://jurnal.iainambon.ac.id/index.php/INT/article/view/1280 taken January $12^{\text {th }}, 2021$.

Van Wart, M., Ni, A., Medina, P. et al. (2020). Integrating students' perspectives about online learning: a hierarchy of factors. Int J Educ Technol High Educ 17, 53. https://doi.org/10.1186/s41239-020-00229-8 taken January 24th, 2021.

Wahono, R.S. (2008). Meluruskan Salah Kaprah Tentang E-Learning. http://romisatriawahono.net/2008/01/23/meluruskan-salahkaprahtentang-e-learning/ taken October $10^{\text {th }}, 2020$.

Wijayanengtias, M., \& Claretta, D. (2020). Student Perceptions of Online Learning During the Covid-19 Pandemic. Kanal: Jurnal Ilmu Komunikasi, 9(1), 16-21. https://doi.org/10.21070/kanal.v9i1.685 taken January 10 ${ }^{\text {th }}, 2021$. 